\title{
1. A SEISMIC-REFLECTION SURVEY OF DSDP SITES 417 AND $418^{1}$
}

\author{
D. A. Senske and R. A. Stephen, Woods Hole Oceanographic Institution, Woods Hole, Massachusetts ${ }^{2}$
}

\begin{abstract}
Single-channel seismic-reflection profiles obtained in the vicinity of DSDP Sites 417 and 418 were studied to determine the relationship between reflectors and sediments cored at these sites. The dense grid of profiles has allowed for the production of maps of depth to basement, depth to sedimentary horizons, bathymetry, and total sediment thickness.

In addition to a reflection from the top of basaltic basement, three reflectors are observed in the sediment sequence; two are correlated to horizons described in the literature, whereas a third is described here for the first time. An AlbianCenomanian reflector is identified as $\beta$ and corresponds closely to the boundary between claystones and chalks of the "black clay facies." The second reflector, middle Eocene in age, corresponds to reflector $\mathrm{A}^{\mathrm{c}}$. Although $\mathrm{A}^{\mathrm{c}}$ correlates to a chert layer in other regions, no cherts were sampled at the level of this reflector at either Site 417 or Site 418. Variability in amplitude of reflector $\mathrm{A}^{\mathrm{c}}$ has also been studied and is suspected to be due to lateral variability in silica diagenesis. We propose that the third previously unidentified reflector, which is Miocene-Oligocene in age, correlates with an ash deposit.

On the basis of observed trends in basement topography an analysis has been carried out to examine the degree of disruption of basement structures by transform faults. Realignment of basement structures suggests $7.0 \mathrm{~km}$ of offset has occurred on a basement strike-slip fault.
\end{abstract}

\section{INTRODUCTION}

A high-resolution, dense coverage seismic-reflection survey was carried out in the vicinity of DSDP Sites 417 and 418 during March and April of 1985. This survey was conducted as part of the multiple reentry reoccupation of Hole $418 \mathrm{~A}$ on Leg 102 of the Ocean Drilling Program (ODP). Objectives of this study are fourfold: (1) correlating reflection profiles with recovered sedimentary core sections to determine lithostratigraphic and chronostratigraphic relationships of major reflecting horizons; (2) generating a detailed bathymetric map of the seafloor; (3) producing maps of overall sediment thickness, depth to specific sedimentary horizons, and depth to basement; and (4) mapping lateral trends in the variation of seismic-wave amplitude of specific reflectors.

\section{THE EXPERIMENT}

The reoccupation of Site 418 involved the use of two vessels: drillship JOIDES Resolution, which did not play an active role in the reflection profiling, and R/V Fred H. Moore of the University of Texas Institute for Geophysics (U.T.I.G.). Profiling was done on the Moore using an 80 -in. ${ }^{3}$ water gun as a source. Data were received on two systems of arrays: a five-channel streamer (from U.T.I.G., Fig. 1) and a single-channel streamer (from Woods Hole Oceanographic Institution). Data were recorded digitally in real time on the Moore using a Texas Instruments DFS-IV acquisition system with a sampling bandwidth of 5 to $148 \mathrm{~Hz}$ (Auroux and Stephen, 1986).

This survey was unique in two respects. First, the use of a water gun allowed us to obtain higher resolution data than have been previously acquired at this site. Second, because this was a two-ship experiment, highly accurate navigational data were obtained by determining bearing and range of the shooting ship from the stationary drillship to a resolution of less than $10 \mathrm{~m}$.

\footnotetext{
${ }^{1}$ Salisbury, M. H., Scott, J. H., et al., 1988. Proc. ODP, Sci. Results, 102: College Station, TX (Ocean Drilling Program).

2 Address: Woods Hole Oceanographic Institution, Woods Hole, MA 02543.
}

The reflection survey encompassed a region covering DSDP Sites 417 and 418 , extending from $24^{\circ} 56^{\prime}$ to $25^{\circ} 13^{\prime} \mathrm{N}$ and $67^{\circ} 58^{\prime}$ to $68^{\circ} 10^{\prime} \mathrm{W}$, as shown in Figure 2. A total of $370 \mathrm{~km}$ of profiles was obtained. The shooting pattern was set up such that lines were oriented along azimuths $110^{\circ}$ and $290^{\circ}$ in the direction of seafloor spreading and $20^{\circ}$ and $200^{\circ}$ perpendicular to the spreading direction. Lines were spaced $2 \mathrm{~km}$ apart on a $16-\mathrm{km}$ grid centered on Hole 418A. Additional lines were shot to the north of Site 417.

\section{BACKGROUND}

The drill holes of principal concern in this paper are DSDP Holes 417D, 418A, and 418B, southwest of Bermuda at the southern end of the Bermuda Rise and just north of the Vema Gap (Fig. 3). Each hole is on anomaly $M 0$ in oceanic crust formed at approximately 118 m.y. B.P. (Aptian through Albian; Kent and Gradstein, 1986).

Holes 417A and 417D penetrated 208 and $343 \mathrm{~m}$ of sediment, respectively. Sediments cored at Hole 417D are similar to those at Hole 417A. Hole 417A penetrated basaltic basement on the flanks of a basement high, thereby missing a 130-m-thick section of Cretaceous sediment sampled at Hole 417D (Donnelly, Francheteau, et al., 1980). As a result, Hole 417D is more useful in seismic stratigraphic correlation.

Sediments sampled at Site 418 holes, $8.75 \mathrm{~km}$ southwest of Site 417, are similar to those at Hole 417D. Two sections, were obtained within $122 \mathrm{~m}$ of each other at this site. Hole $418 \mathrm{~A}$ is a multiple reentry, deep-penetration hole. It was drilled specifically to recover basement rock and, as a consequence, obtained an incomplete sediment section. Conversely, Hole 418B was drilled to recover a complete sediment record and obtained only $10.5 \mathrm{~m}$ of basement section (Donnelly, Francheteau, et al., 1980).

Information from the drill sites indicates the overall sequence of sediments is predominately pelagic and zeolitic clays with the exception of a 42- to 76-m-thick section of claystones and carbonates at the base of the sediment column. Total sediment thickness at the four holes ranges from $208 \mathrm{~m}$ at Hole 417A to $343 \mathrm{~m}$ at Hole 417D. Sediment thicknesses, hole locations, and chronostratigraphic units of oldest sediment at each site are summarized in Table 1. 


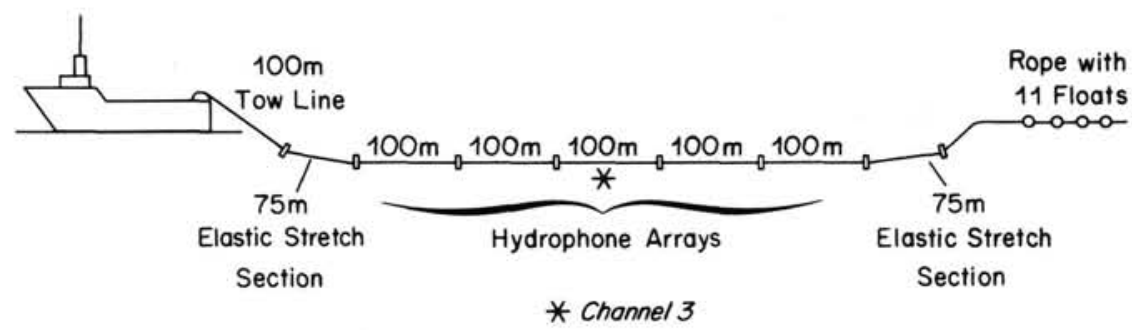

Figure 1. Schematic of R/V Fred H. Moore five-channel streamer. Interpretations in this paper are based on single-channel data recorded on channel 3.

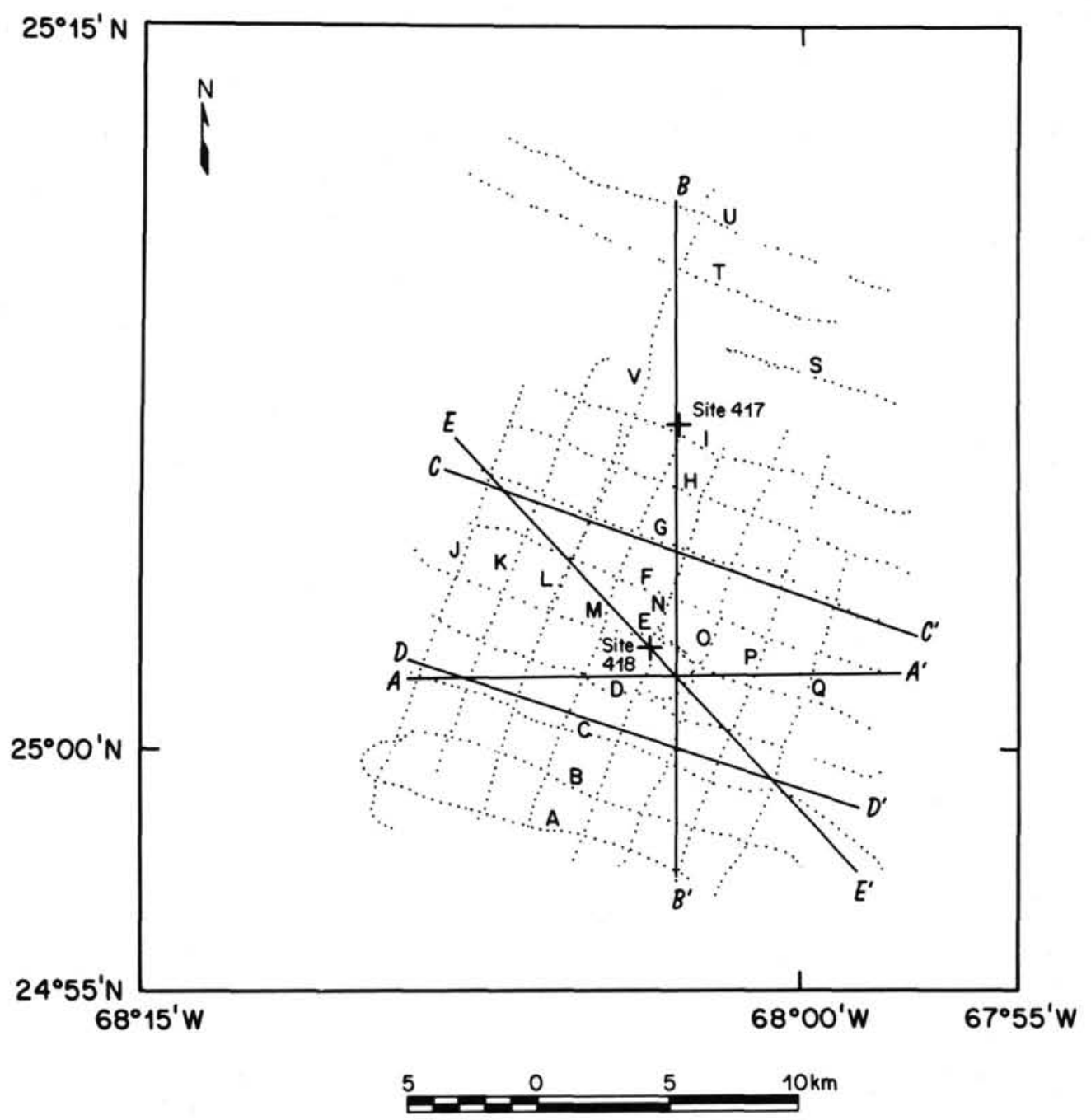

Figure 2. Shooting pattern for the reflection experiment. Track lines are oriented perpendicular $(\mathrm{J}-\mathrm{Q}, \mathrm{V})$ and parallel (A-I, S, T, U) to the direction of seafloor spreading. Digital data were not recorded for segments of lines $\mathrm{Q}$ and $\mathrm{S}$ and all of line R. Lines $\mathrm{A}-\mathrm{A}^{\prime}, \mathrm{B}-\mathrm{B}^{\prime}, \mathrm{C}-\mathrm{C}^{\prime}, \mathrm{D}-\mathrm{D}^{\prime}$, and $\mathrm{E}-\mathrm{E}^{\prime}$ mark locations of cross sections shown in Figure 11.

Present seafloor morphology in this region is controlled by bottom currents resulting in the formation of sediment drifts (Emery and Uchupi, 1984). This is confirmed by sediment drifts observed on $3.5-\mathrm{kHz}$ data. The regional geologic setting indicates the seafloor in the vicinity of the drill sites is characterized by hemipelagic turbidite deposits and pelagic sediments with a number of basement outcrops, as well as sediment drifts (Fig. 4).

\section{DATA REDUCTION AND INTERPRETATION} Chronostratigraphic and Lithostratigraphic Correlation

Four specific reflecting horizons were identified as mappable surfaces. A horizon was deemed mappable if it was found to be laterally continuous between adjacent profiles within the survey area. In the initial analysis we assigned a color to each reflector 


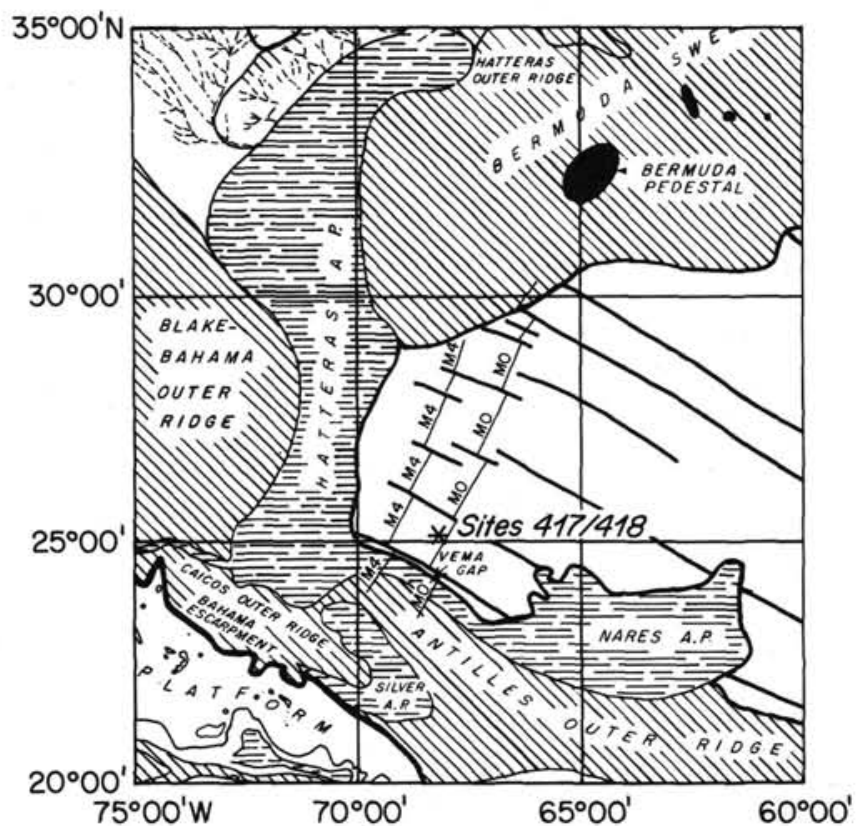

Figure 3. Location of DSDP Sites 417 and 418 with respect to anomaly $M 0$ and local fracture zones. Regional physiographic provinces are shown (from Chart IIA, Emery and Uchupi, 1984).

in stratigraphic order: blue, yellow, green, and red. The blue reflector corresponds to the top of basement, whereas the three shallower reflectors (yellow, green, and red) are within the sediment sequence. Table 2 summarizes stratigraphic relationships of reflectors.

Track lines passed as close as 165 (Site 418 ) and $300 \mathrm{~m}$ (Site $417)$ to the drill sites, allowing direct correlation of seismic sequences and cored sediment sections. In order to define the velocity structure of the sediment column, a total of 113 laboratory measurements were made on individual sediment samples to determine $P$-wave velocity (Donnelly, Francheteau, et al., 1980 ). Values were found to range from 1.41 to $5.19 \mathrm{~km} / \mathrm{s}$. Velocities ranging from 1.85 to $5.19 \mathrm{~km} / \mathrm{s}$ measured on a $28-\mathrm{m}$ thick near-basement carbonate layer (Hole 417D) and sediment containing chert stringers (Hole 418B) were not used in calculating average velocity because they are not representative of the overall sediment structure. This allowed us to discard six data points. Average velocity calculated using the remaining data was found to be $1.57 \mathrm{~km} / \mathrm{s}$. This value is believed to be lower than true sediment velocity because laboratory conditions do not reflect in-situ conditions.

In addition to laboratory measurements, well-logging data for Hole 417D obtained $P$-wave velocities for lithologic Units

Table 1. Summary of site locations and total thickness of sediments penetrated (from Donnelly, Francheteau, et al., 1980).

\begin{tabular}{ccccc}
\hline Hole & Latitude & Longitude & $\begin{array}{c}\text { Total sediment } \\
\text { thickness }(\mathrm{m})\end{array}$ & $\begin{array}{c}\text { Chronostratigraphic unit } \\
\text { corresponding to } \\
\text { oldest sediment }\end{array}$ \\
\hline $417 \mathrm{~A}$ & $26^{\circ} 06.63^{\prime} \mathrm{N}$ & $68^{\circ} 02.48^{\prime} \mathrm{W}$ & ${ }^{2} 208$ & Upper Cretaceous \\
$417 \mathrm{D}$ & $25^{\circ} 06.69^{\prime} \mathrm{N}$ & $68^{\circ} 02.81^{\prime} \mathrm{W}$ & 343 & Lower Aptian \\
$418 \mathrm{~A}$ & $25^{\circ} 02.10^{\prime} \mathrm{N}$ & $68^{\circ} 03.44^{\prime} \mathrm{W}$ & 324 & Lower Aptian \\
$418 \mathrm{~B}$ & $25^{\circ} 02.08^{\prime} \mathrm{N}$ & $68^{\circ} 03.45^{\prime} \mathrm{W}$ & 319.5 & Upper Aptian \\
\hline
\end{tabular}

${ }^{\text {a }}$ The sediment section at Hole $417 \mathrm{~A}$ is missing approximately $130 \mathrm{~m}$ of Cretaceous sediments sampled at Hole 417D.
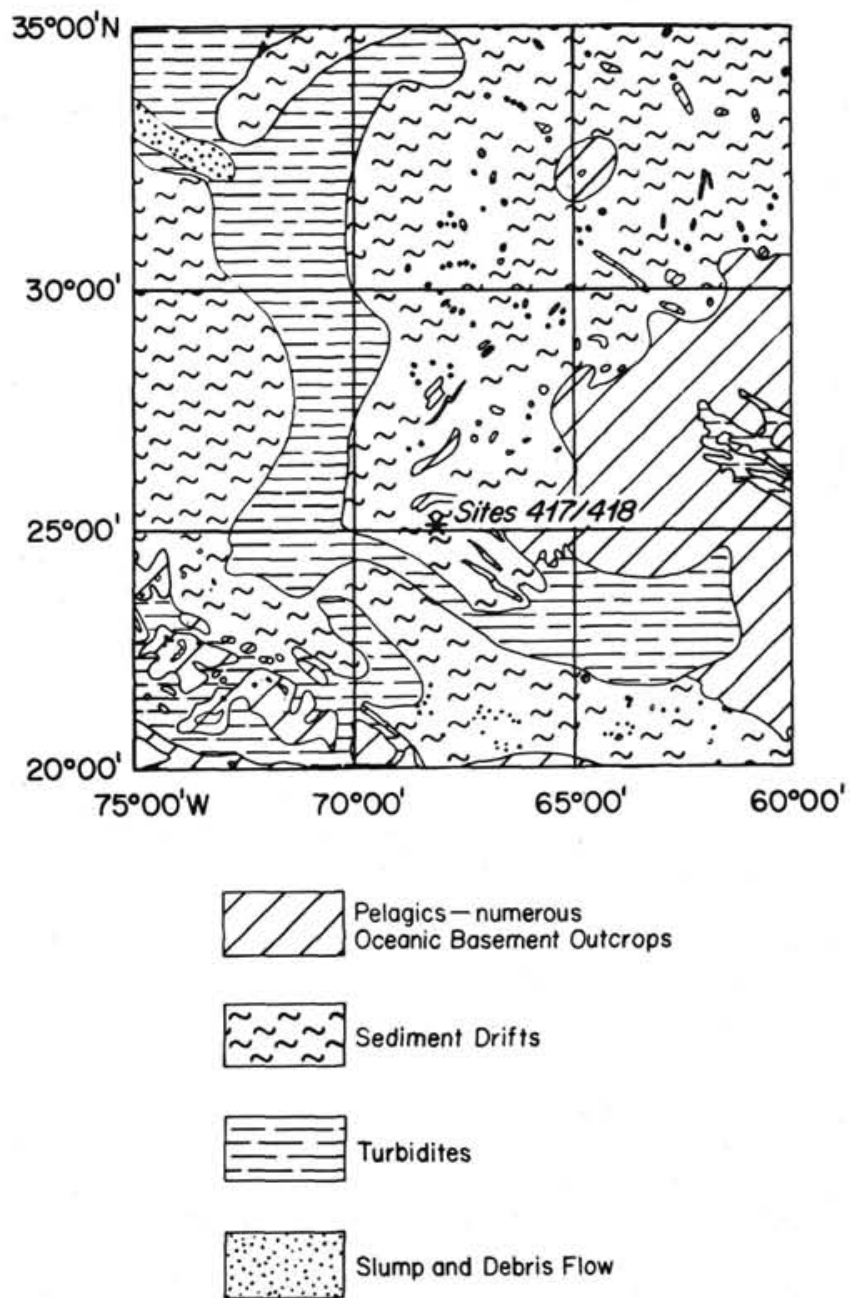

Figure 4. Dominant sedimentary regimes (Miocene and younger) in the vicinity of Sites 417 and 418 . Both sites are located in a region of sediment drifts (from Chart XA, Emery and Uchupi, 1984).

Table 2. Summary of stratigraphic relationships between reflectors.

\begin{tabular}{cccc}
\hline $\begin{array}{c}\text { Initial designation } \\
\text { of reflector }\end{array}$ & $\begin{array}{c}\text { Correlated } \\
\text { reflector }\end{array}$ & $\begin{array}{c}\text { Lithologic } \\
\text { correlation }\end{array}$ & Age correlation \\
\hline Blue & $\beta$ & $\begin{array}{c}\text { Top of basaltic } \\
\text { basement } \\
\text { Claystone and } \\
\text { nannofossil chalk }\end{array}$ & Aptian \\
Yellow & A $^{\mathrm{c}}$ & $\begin{array}{c}\text { Pelagic zeolite-bearing } \\
\text { clays, chert(?) }\end{array}$ & Miocene-Oligocene \\
Red & $?$ & $\begin{array}{c}\text { Zeolitic clay and ash } \\
\text { deposit }\end{array}$ & Miocene-Oligocene \\
\hline
\end{tabular}

IV through VIII (see Donnelly, Francheteau, et al., 1980, for criteria used in defining lithologic units). Velocities for the predominantly clay units (IV and V), which are representative of a major percentage of cored sediments, were found to be between 1.70 and $1.75 \mathrm{~km} / \mathrm{s}$. Because no data were obtained for sedimentary Units I through III that were expected to have lower velocities, we feel a velocity of $1.60 \mathrm{~km} / \mathrm{s}$ is adequate for average sediment velocity and represents a compromise between laboratory measurements and well-logging results. 
While occupying Hole $418 \mathrm{~A}$, sonobuoys were deployed and four refraction lines were shot using explosives. Data from this experiment are not useful for study of the sediment velocity structure. The shot spacing $(0.5-2.0 \mathrm{~km})$ was too wide to adequately sample the shallow sediments, and the sonobuoys drifted by $16 \mathrm{~km}$ during the shooting.

\section{Basement}

Basement lithology is characterized by gray to greenish gray massive basalts with overlying pillow basalts. The basement reflection, at $0.42 \mathrm{~s}$ two-way traveltime (TWT) below seafloor (bsf) for Hole 417D and $0.36 \mathrm{~s}$ TWT bsf for Holes 418A and $418 \mathrm{~B}$, results from combined velocity and density contrasts at the basalt/sediment boundary. Average velocity and density of the basalt are $5.0 \mathrm{~km} / \mathrm{s}$ and $2.65 \mathrm{~g} / \mathrm{cm}^{3}$, respectively. Carbonate sediments sampled above the basalt have velocity values ranging from 1.62 to $1.85 \mathrm{~km} / \mathrm{s}$ and a density of $1.82 \mathrm{~g} / \mathrm{cm}^{3}$. The basalt/sediment contact was not recovered at Holes $418 \mathrm{~A}$ and 418B. At Hole 417D it was partially recovered, and no evidence of recrystallization or baking of the sediments was observed. This suggests that the contact is depositional (Donnelly, Francheteau, et al., 1980).

Variability of seismic-wave amplitude for the basement reflector was examined. An attempt to correlate regions of high amplitude with basement topography proved to be unsuccessful. No general trends in amplitude and topography were observed, which may be due to the large number of side echos caused by the rough basement surface.

\section{Horizon $\beta$}

Horizon $\beta$ corresponds to a well-defined boundary in the western North Atlantic between dark green-gray to black claystones and underlying limestones or chalks (Tucholke and Mountain, 1979). From drilling evidence the age of this horizon is generally Hauterivian to Barremian, but from the location of its eastward pinch-out on oceanic crust it has been suggested to be time-transgressive. Horizon $\beta$ marks a transition from carbonate accumulation to noncalcareous sedimentation caused by an Early Cretaceous rise in the carbonate compensation depth (CCD). Furthermore, the sedimentary record shows a change from a well-oxygenated regime allowing the deposition of calcareous sediments to an environment characterized by clays and silts, with alternating low-oxygen and anoxic conditions (Tucholke, 1981; Tucholke and Vogt, 1979; Lancelot et al., 1972).

A reflector (yellow) corresponding to Horizon $\beta$ was identified on line N, which passed near Site 418 (Figs. 5A and 5B). However, another line in the same vicinity failed to detect the reflection (Figs. 6A and 6B). This is not completely unexpected because the reflector is very near basement, and diffraction hyperbolae from rough basement will tend to mask the sedimentary reflector. Profiles obtained with a deep-towed hydrophone and a surface air gun, however, do show a near-basement sedimentary reflector, most probably horizon $\beta$ (Purdy et al., 1980; Tucholke, 1981).

The reflector at Site $418,0.3 \mathrm{~s}$ TWT, calculated at $240 \mathrm{~m}$ below seafloor (mbsf) in the sediment section (Figs. 5A and 5B), corresponds closely to the boundary between a lower unit of chalk, claystone, marl, and radiolarian sand (Albian-Cenomanian), Unit VI, and an upper unit of zeolitic clay (Upper Cretaceous?), Subunit $\mathrm{Vb}$.

Unit VI is generally described as dominated by a lower sequence of light green claystones and overlying nannofossil chalks. Laminated organic-rich black clays with burrowed green clays are present throughout. Groups of sediments analogous to this sequence of claystones and chalks have been identified at other Atlantic DSDP sites and have been grouped together as the "black clay facies."
Examination of Unit VI shows that the base of the unit is defined by a transition upward from nannofossil chalk and marl to chert or siliceous mudstones (top of Unit VII). Above the mudstones, three major lithologies are present in a claystone sequence: (1) light green claystones, (2) black organic pyritic clays, and (3) coarse radiolarian sands. The zone of transition between these claystones and an upper sequence of chalks of Unit VI is distinguished by black clays, radiolarian sands, and sandy pyritic clay. The chalks are characterized by white to pale green nannofossil burrowed chalks, laminated chalks, greenish gray claystones, and marls. A sharply defined contact of vitreous brown chert marks the boundary between Unit VI and an upper clay of Subunit $\mathrm{Vb}$ and is distinguished by interbedded dark brown, yellow brown to pale orange, and pale green zeolitic clays (Donnelly, Francheteau, et al., 1980).

Core recovery for Unit VI and Subunit Vb is $27 \%$ and $45 \%$, respectively, resulting in a degree of uncertainty in correlating lithologic sequences with reflectors on the seismic records. On the basis of our velocity structure, horizon $\beta$ occurs in an unsampled region intermediate between nannofossil chalks and an upper layer of light greenish gray claystone.

The impedance contrast between the chalks and the overlying clay and claystone results in the generation of a significant reflector. If this reflector is indeed analogous to horizon $\beta$ then it is time-transgressive from Hauterivian/Barremian to Albian/ Cenomanian.

The "black clay facies," Unit VI at Hole 417D (280 to $326 \mathrm{mbsf}$ in the section), is dominated by four major lithologies with varying degrees of interbedding. These are (1) radiolarian sands, (2) nannofossil chalks and marls, (3) organic-carbon-rich pyritic and phosphatic black clays, and (4) green claystones, partly zeolitic, phosphatic, or dolomitic. The base of this unit is defined by a layer of radiolarian- and foraminifer-bearing limestone that marks the boundary between an upper sequence of claystones and chalks (Unit VI) and a lower sequence (Unit VII) of radiolarian sandstone, claystone, and nannofossil chalk, which shows evidence of turbidite cycles in recovered sediments (Donnelly, Francheteau, et al., 1980). The lower sediment sequence of Unit VI is characterized by interlayered phosphatic, dolomitic(?), organic pyritic claystones, clayey nannofossil chalks, and radiolarian- and foraminifer-bearing nannofossil chalks, whereas zeolitic clays to zeolitic, dolomitic(?), phosphatic claystones are found at the top of the unit. Black clay interlayers are also an important lithology.

A reflector believed to correspond to horizon $\beta, 0.28 \mathrm{~s}$ TWT bsf, is found at 220 mbsf in the sediment section at Hole 417D (Fig. 7). This appears to be too shallow and is inconsistent with the other drill sites. Because the nearest profiling line is $300 \mathrm{~m}$ south of the hole, it must be assumed that the surface dips approximately $11^{\circ}$ northward toward the drill site, which would place it near the contact between the "black clay facies" and an upper layer of zeolitic clay. Due to equipment failure, digital data for line $R$ and a segment of line S in the vicinity of Site 417 were lost. Therefore, the nature of horizon $\beta$ near Hole 417D can only be inferred.

\section{Horizon $\mathbf{A}^{c}$}

In their study of sedimentary structures near proposed drill sites in the North Atlantic, Ewing and Ewing (1963) identified a horizon that they designated as "A." It has been established that their horizon A represents a number of reflections from unique interfaces. On much of the Bermuda Rise, the strongest reflector of the horizon A complex is horizon $\mathrm{A}^{\mathrm{c}}$. This horizon correlates with a diagenetic unit of upper lower to lower middle Eocene chert (Tucholke, 1979, 1981) that can occur in a variety of host sediments (e.g., hemipelagic clays or turbidite deposits) (Tucholke and Mountain, 1979). A weak reflector, designated 

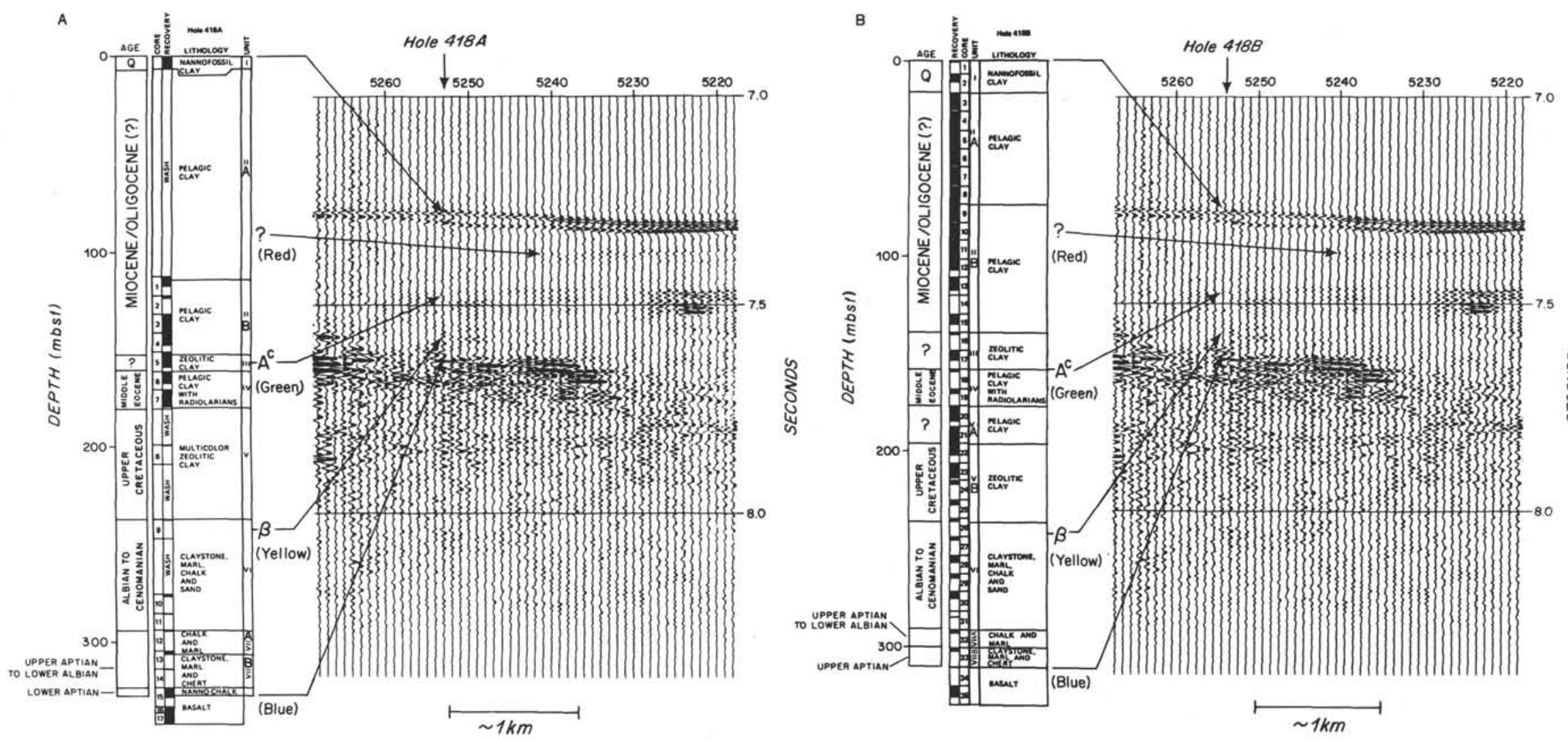

Figure 5. Seismic profile (line N) correlated with sediments at Holes 418A (A) and 418B (B). Coring penetrated $324 \mathrm{~m}$ of sediment at Hole 418A and 319.5 m at Hole 418B. Hole 418B is located $122 \mathrm{~m}$ north of Hole 418A. Reflectors $\mathrm{A}^{\mathrm{c}}$ and $\beta$ are identified on the cored section. A weak Miocene-Oligocene reflector is also identified. Every tenth shot point is labeled on the profile. 

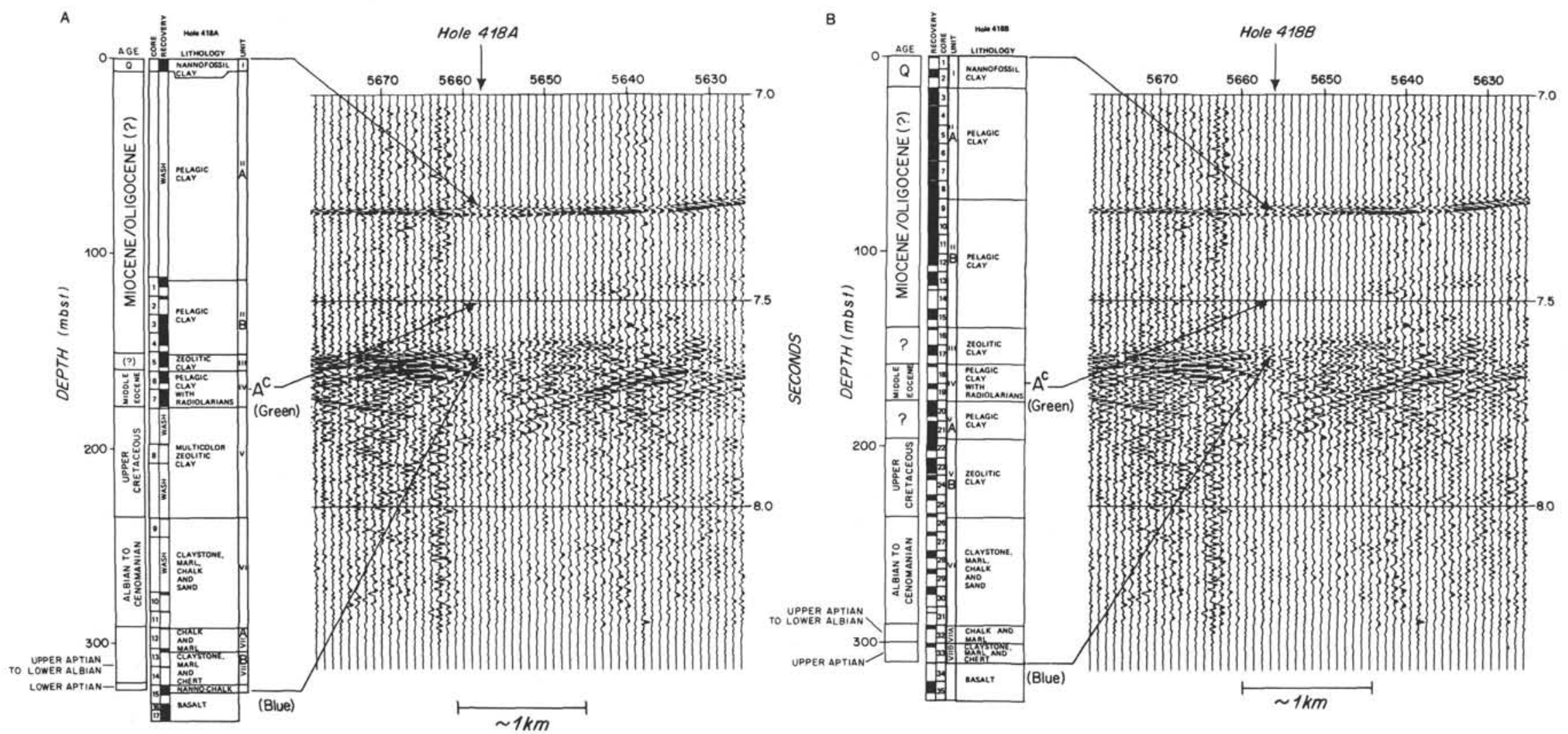

ई̊.

Figure 6. Correlation of line O with Holes 418A (A) and 418B (B). Only reflector $\mathrm{A}^{\mathrm{c}}$ can be identified on the profile. Deeper reflectors are masked by diffraction hyperbolae. Every tenth shot point is labeled on the profile. 


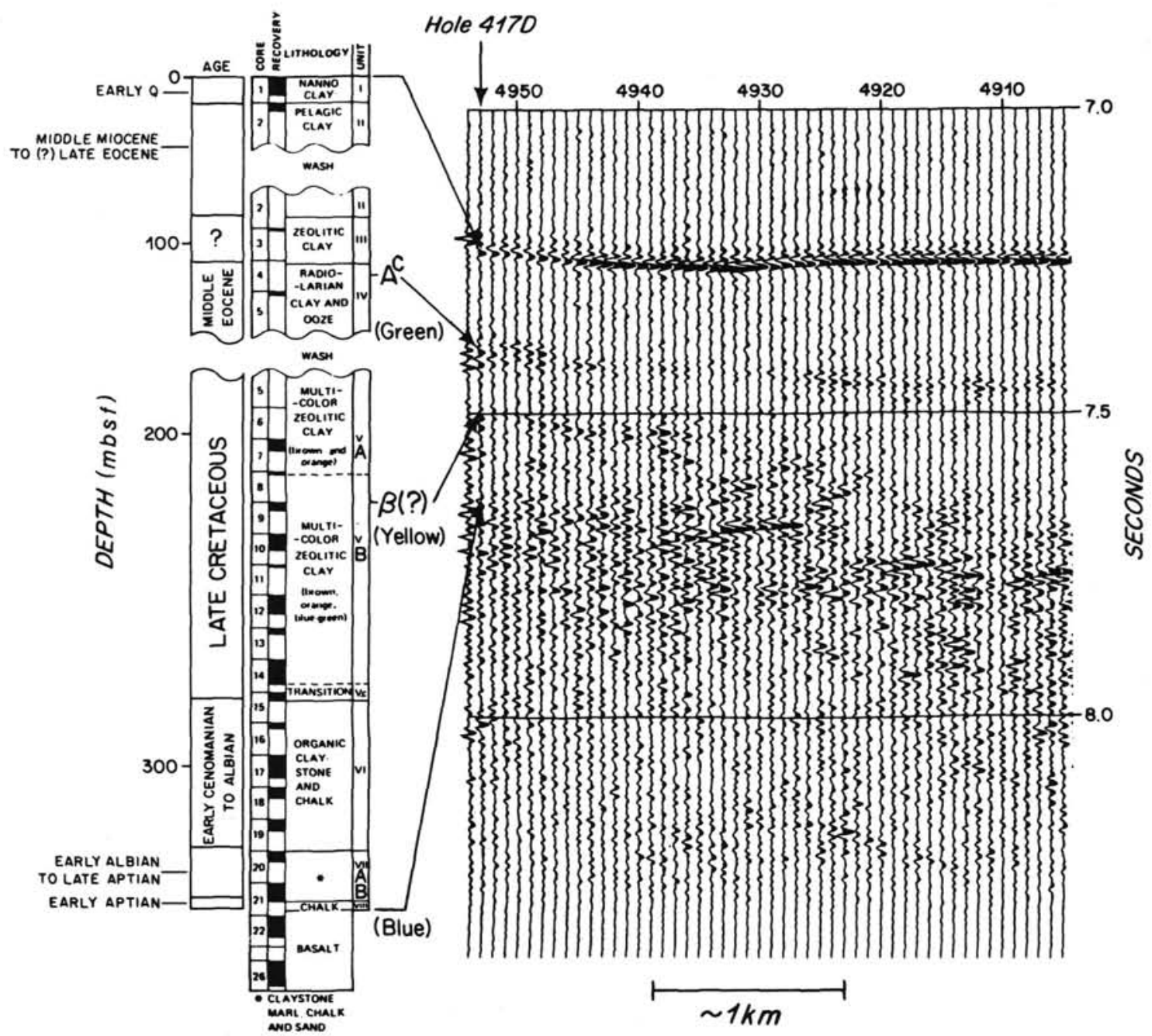

Figure 7. Seismic profile (line M) correlated with stratigraphic section at Hole 417D, at which $343 \mathrm{~m}$ of sediment were penetrated. Reflectors $A^{c}$ and $\beta($ ?) are identified. Every tenth shot point is labeled on the profile.

on our profiles as green, correlated to middle Eocene sediments at both Sites 417 and $418,0.18$ and $0.20 \mathrm{~s}$ TWT bsf (Figs. 5-7). This is probably equivalent to Horizon $\mathrm{A}^{\mathrm{c}}$. Lithologic correlation with both sites indicates that sediments at the level of this reflector are made up of dark reddish brown pelagic clay containing abundant zeolites. Radiolarian debris and sponge spicules are also present. Trace amounts of quartz and feldspar suggest a terrigenous source for some of the sediment. Cherts, however, are absent at this level at both sites. Horizon $\mathrm{A}^{\mathrm{c}}$ is weak at the drill sites, which indicates a low-impedance contrast that we attribute to the absence of cherts. Elsewhere within the survey area, horizon $\mathrm{A}^{\mathrm{c}}$ is a very strong reflector, possibly indicating an abundance of cherts.

\section{Wave-Amplitude Variation}

A qualitative analysis was made of the relative variability of seismic-wave amplitude at horizon $\mathrm{A}^{\mathrm{c}}$. Wave amplitude was mapped into one of three categories: (1) high amplitude, (2) moderate amplitude, and (3) low amplitude (Fig. 8). Horizon $\mathrm{A}^{\mathrm{c}}$ shows a correlation of high-reflection amplitude with the general northwest trend of topography. The reason for this is not completely understood, but it may be related to the diagenesis of the chert layer. It is also observed that areas of highest amplitude correlate relatively well with the thickest sediments, sug- gesting that amplitude variation may be related to degree of compaction and porosity of sediment.

\section{Red Horizon}

A very weak reflector that we have designated the red reflector is observed at $0.11 \mathrm{~s}$ TWT bsf in sediments of Miocene-Oligocene age and is labeled as ? in Figures 5A and 5B. Sediments at the level of this reflector are composed mainly of terrigenous clays (illite, chlorite, and kaolinite) and some quartz and feldspar. Beds of graded devitrified ash are also present. The terrigenous nature of the sediments suggests the possibility of deposition by turbidity currents. The surface giving rise to the red reflector is not well defined. Beds of volcanic ash recovered in sediments near the level of this reflector may be the source of the reflection.

\section{MAPS OF BASEMENT, SEDIMENTARY HORIZONS, AND SEAFLOOR TOPOGRAPHY}

\section{Basement}

Basement (Fig. 9) is characterized by a variety of features divisible into two topographic provinces: (1) large-scale structural features, predominately topographic highs, 5 to $13 \mathrm{~km}$ in length and with 75 to $150 \mathrm{~m}$ of relief; and (2) small hills and valleys be- 


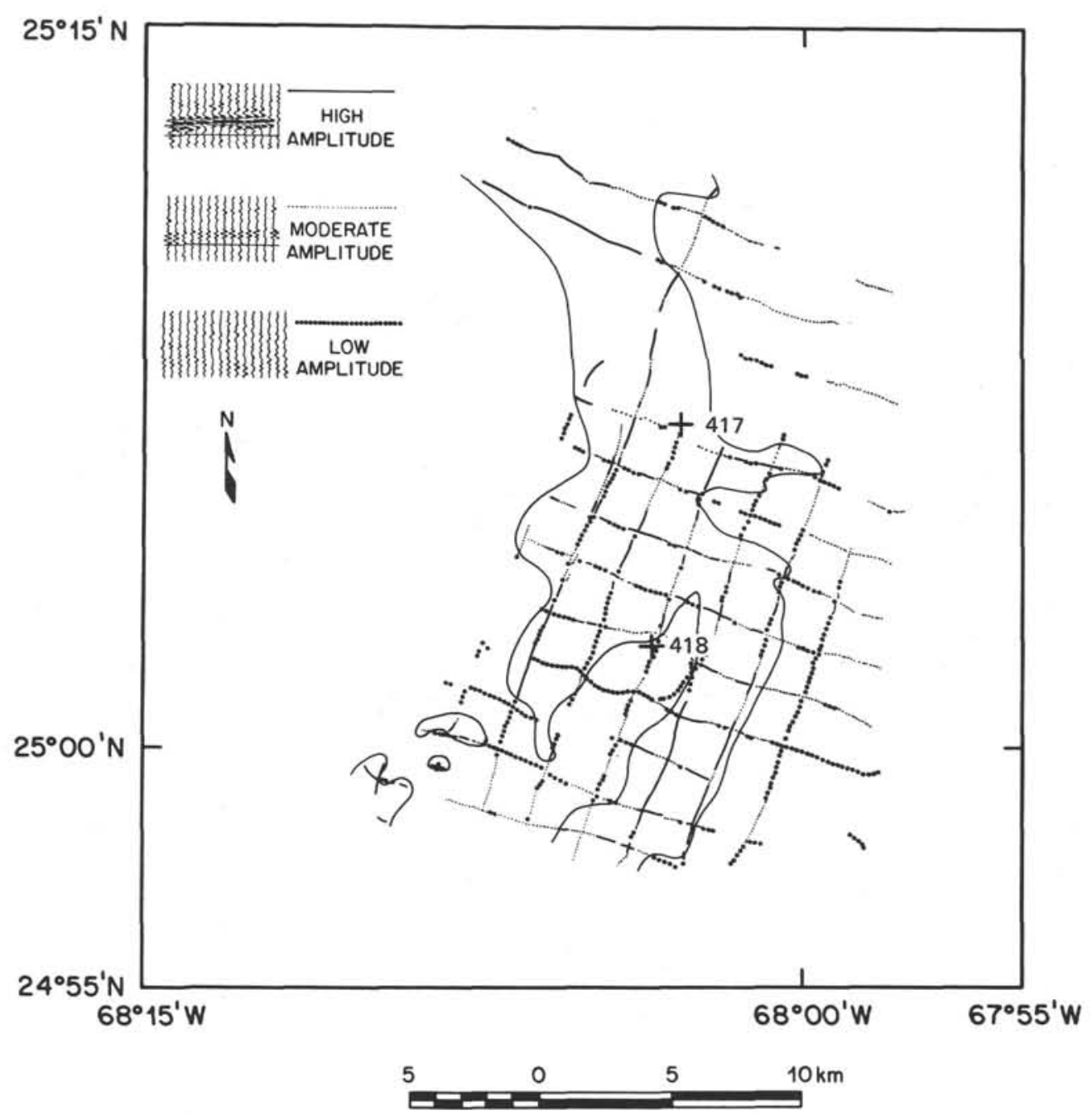

Figure 8. Qualitative comparison of seismic-wave amplitude variation for horizon $\mathrm{A}^{\mathrm{c}}$. Regions of high amplitude trend NNW, similar to topography. The contour encloses an area of highest amplitude.

tween regions of high topography, 2 to $4 \mathrm{~km}$ in length, with 50 to $75 \mathrm{~m}$ of relief. There are two dominant regions of topographic highs in the survey area. The first corresponds to a ridge or plateau, oriented north-northeast and attaining a minimum depth of approximately $5675 \mathrm{~m}$, along the eastern perimeter of our survey area (Fig. 9). The second feature, a steeply sloping basement high $(5606 \mathrm{~m})$, dominates the southwestern corner of the survey area and is adjacent to a region of topographic depressions $(\sim 5900 \mathrm{~m})$. Another basement high is found $5 \mathrm{~km}$ southwest of Site 417. The terrain between basement highs is characterized by small valleys and hills with relief not exceeding $75 \mathrm{~m}$. Evidence of a major basement trough, with $\sim 300 \mathrm{~m}$ of topographic relief, is seen in the northwestern corner of the survey area. A low east-west ridge separating two areas of topographic depressions divides the survey area nearly in half. Basement structures are oriented both parallel and perpendicular to the spreading axis. Analysis of topographic trends suggests the presence $4.5 \mathrm{~km}$ northeast of Site 417 of a major strike-slip fault striking $\mathrm{N} 69^{\circ} \mathrm{W}$. Realignment of basement structures, labeled with arrow pairs $A-A^{\prime}$ and $B-B^{\prime}$ in Figure 9, suggests $7 \mathrm{~km}$ of left-lateral offset has occurred on this fault.

\section{Horizon $\beta$}

Structural contours of horizon $\beta$ appear to be controlled by basement structures. Information about this surface is spotty at best, making it difficult to correlate contours of equal depth. General contour trends are northeast, with extremes in horizon depth ranging from 5568 to $5850 \mathrm{~m}$. Major trends that reflect the regional slope of basement show a gradual downward slope from east to west (Figs. 10 and 11, cross sections A to E). The western part of the region is observed to be dominated by basement highs partially covered with sediments.

\section{Horizon $\mathbf{A}^{\mathrm{c}}$}

Analysis of horizon $A^{c}$ (Fig. 12) shows it to have the greatest lateral continuity of all the sedimentary horizons. Like basement and horizon $\beta$, this horizon displays a regional trend of increasing depth from east to west. The eastern portion of the region is dominated by a relatively flat ridge that dips west. Two basement highs are prevalent in the west. Relief ranges from 5483 to $5775 \mathrm{~m}$.

Topographic trends of this horizon are similar to those of the modern seafloor, horizon $\beta$, and basement. This tends to indicate pelagic drape, modified by local mass movement and possibly by currents.

\section{Red Horizon}

Because the reflection associated with this horizon is very weak, very little information regarding it was recovered. This implies a degree of uncertainty associated with contouring and 


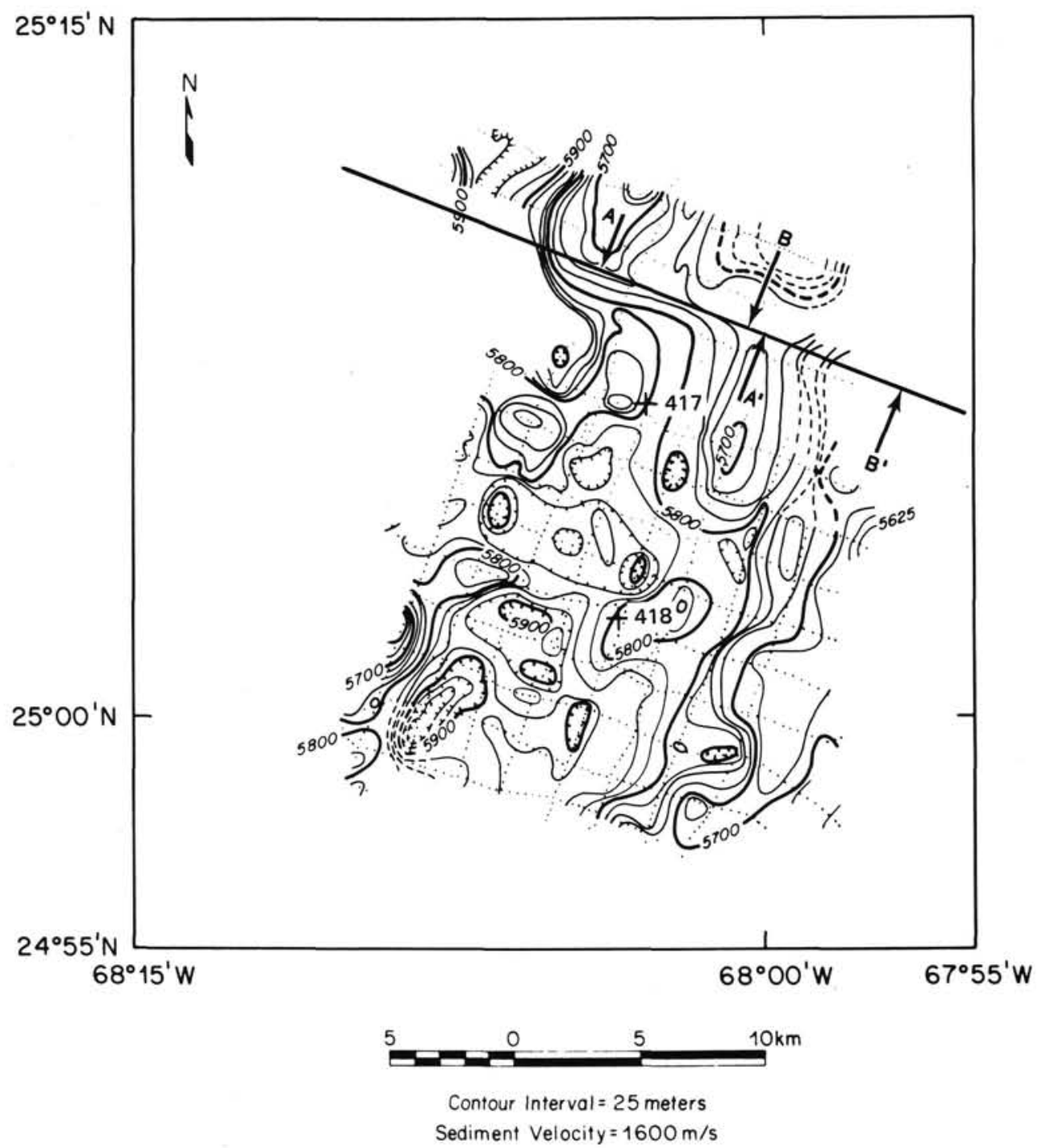

Figure 9. Basement topography ( $\mathrm{m}$ depth to basement). Coring penetrated basement on the flanks of basement highs at both Sites 417 and 418. Structural features trend NNE. Evidence of a deep basement depression is seen in the northwest corner of the study area. A left-lateral strike-slip fault is observed northeast of Site 417. Arrows show offset of basement structures as described in text.

interpretation. Its lateral extent is confined to the general vicinity of Site 418 and a small region to the southwest of the same site. Absolute topographic relief exceeds no more than $245 \mathrm{~m}$ with extremes ranging from 5430 to $5675 \mathrm{~m}$ (Fig. 13).

\section{Seafloor Topography}

A map of the seafloor was produced from echo-sounding data. Continuous $3.5-\mathrm{kHz}$ soundings were made continually throughout the survey, during the oblique seismic experiment (Swift and Stephen, this volume) as well as the reflection survey. Data from the 1976 Lynch survey (Rabinowitz et al., 1980) of this site were available to us and have also been incorporated into the bathymetric data base. Values for depth were recorded in uncorrected fathoms and later converted to corrected meters using Matthews tables. The bathymetric data show Sites 417 and 418 to be located at the edge of a broad valley. The region is dominated by a gentle regional slope with depth increasing from east to west. Extremes in depth correspond to a bathymetric high of $5346 \mathrm{~m}$ in the northeast corner of the study area and a low of $5616 \mathrm{~m}$ in the southwest section of the survey area. Depth contours generally trend north and west (Fig. 14).

\section{Sediment Thickness}

An isopach map of total sediment thickness (Fig. 15) indicates there is little variation from a mean sediment thickness of $300 \mathrm{~m}$. Excursions from the mean range from an isolated $500-\mathrm{m}$ thick sequence of sediments over the northwestern basement trough to sediments 100 to $250 \mathrm{~m}$ thick associated with longwavelength basement structures, specifically the southwestern basement high and eastern basement ridge. The relatively uniform nature of the sediment thickness seems to indicate that short-wavelength depressions were filled early in the sedimentation history of the region. Subsequent sedimentation has been characterized mainly by draping of sediments; present modification is by bottom currents.

\section{SUMMARY AND DISCUSSION}

Three major seismic stratigraphic horizons have been identified and correlated to lithostratigraphic and chronostratigraphic units at DSDP Sites 417 and 418 , and a fourth is described here for the first time. Each horizon marks a specific episode in the sedimentation record of the region. 


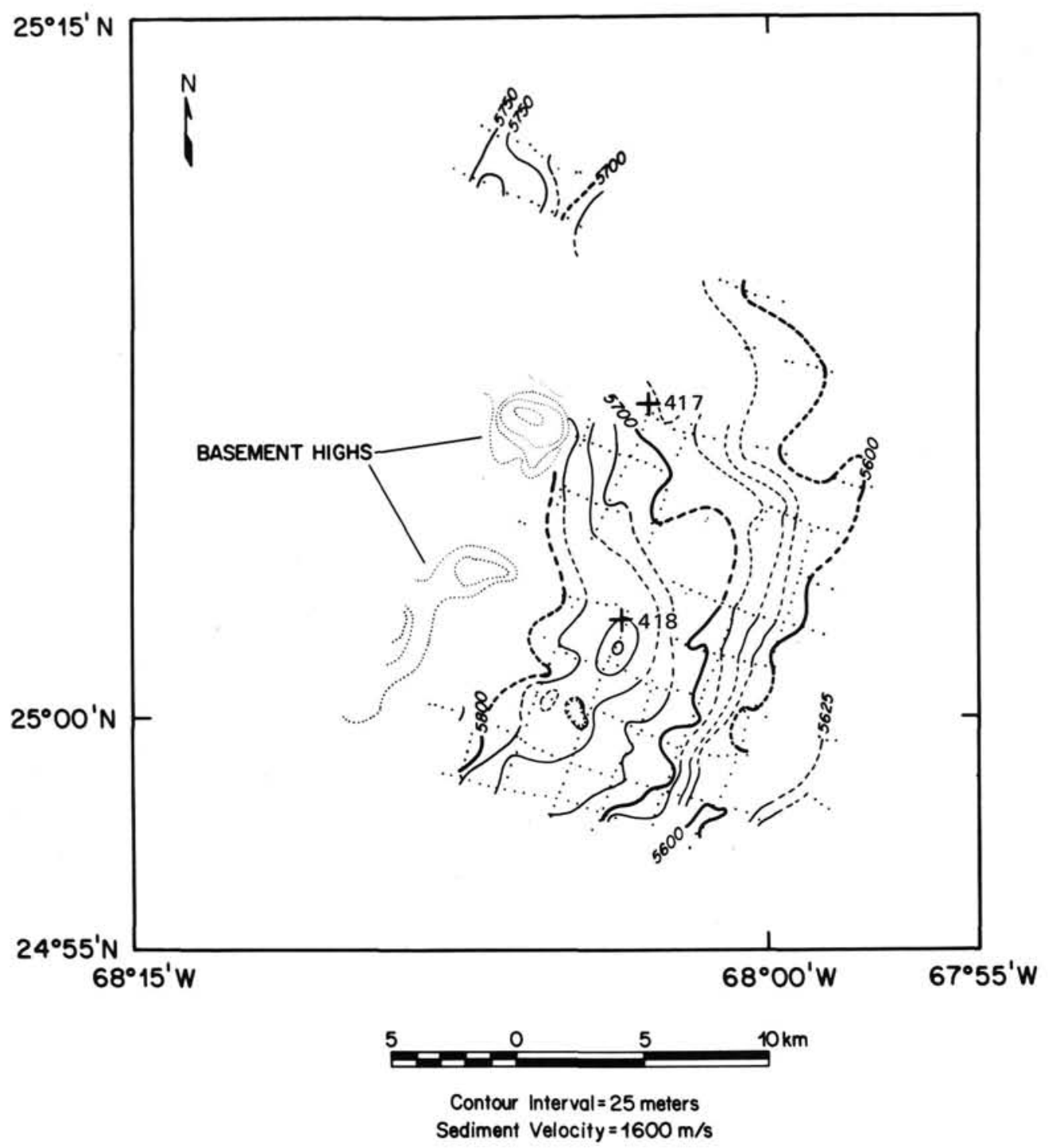

Figure 10. Depth to Albian-Cenomanian horizon $\beta$. Contours follow a general NNE trend similar to basement. Horizon $\beta$ pinches out in the west near basement highs.

Sediments sampled at the contact between basaltic basement and the overlying sedimentary unit place the time of crustal formation sometime near early Aptian. The overlying sediments are marls, cherts, chalks, and claystones that vary in color from black to blue green. Deposition of predominately carbonate sediments continued up to Albian-Cenomanian, after which most of the carbonates disappeared and the sedimentary regime was dominated by pelagic clays with traces of terrigenous sediment. The boundary marking the transition between these two environments in the basin to the west has been seismically identified as horizon $\beta$. Tucholke (1979) places an upper limit on the age of horizon $\beta$ as Hauterivian. However, in our study area the horizon may be as young as Cenomanian. It has been suggested that horizon $\beta$ is a boundary marking a rise in the CCD and that it may be a time-transgressive facies boundary (Tucholke, 1981). Our data support this concept. Reflectors corresponding to this horizon are near basement and difficult to detect. Our data are presented to show true reflector amplitude, which also makes it difficult to detect near-basement reflectors. It does, however, allow us to examine lateral variation in reflector amplitude. Although horizon $\beta$ is difficult to detect on Figures 5 and 7 , it is observed as a strong reflection in other sections of the survey area. On the basis of both seismic and lithologic data, we suggest horizon $\beta$ reaches its maximum eastern extent in the vicinity of Sites 417 and 418 .

Cenomanian to middle Eocene sediments are predominantly dark grayish brown to red brown pelagic clays. A middle Eocene reflector has been equated with horizon $\mathrm{A}^{\mathrm{c}}$. Elsewhere horizon $\mathrm{A}^{\mathrm{c}}$ correlates with cherts. However, no cherts were sampled at this level at Sites 417 and 418. The absence of a chert layer does not rule out the reflector as being $A^{c}$. It is believed that the cherts provide an appropriate acoustic impedance to produce a strong reflection, but both drill sites show the reflector to be weak, possibly indicating a depletion of cherts. Elsewhere in the region, horizon $\mathrm{A}^{\mathrm{c}}$ shows up as a relatively strong reflection. Amplitude data indicate lateral variability in chert development. Holes drilled at both Sites 417 and 418 penetrated regions where $\mathrm{A}^{\mathrm{c}}$ is characterized by low amplitude where little if any cherts are expected.

Recent unpublished modeling data using vertical incidence synthetic seismograms and a refined velocity structure suggest the reflector identified as $\mathrm{A}^{\mathrm{c}}$ may be an erosional surface rather 

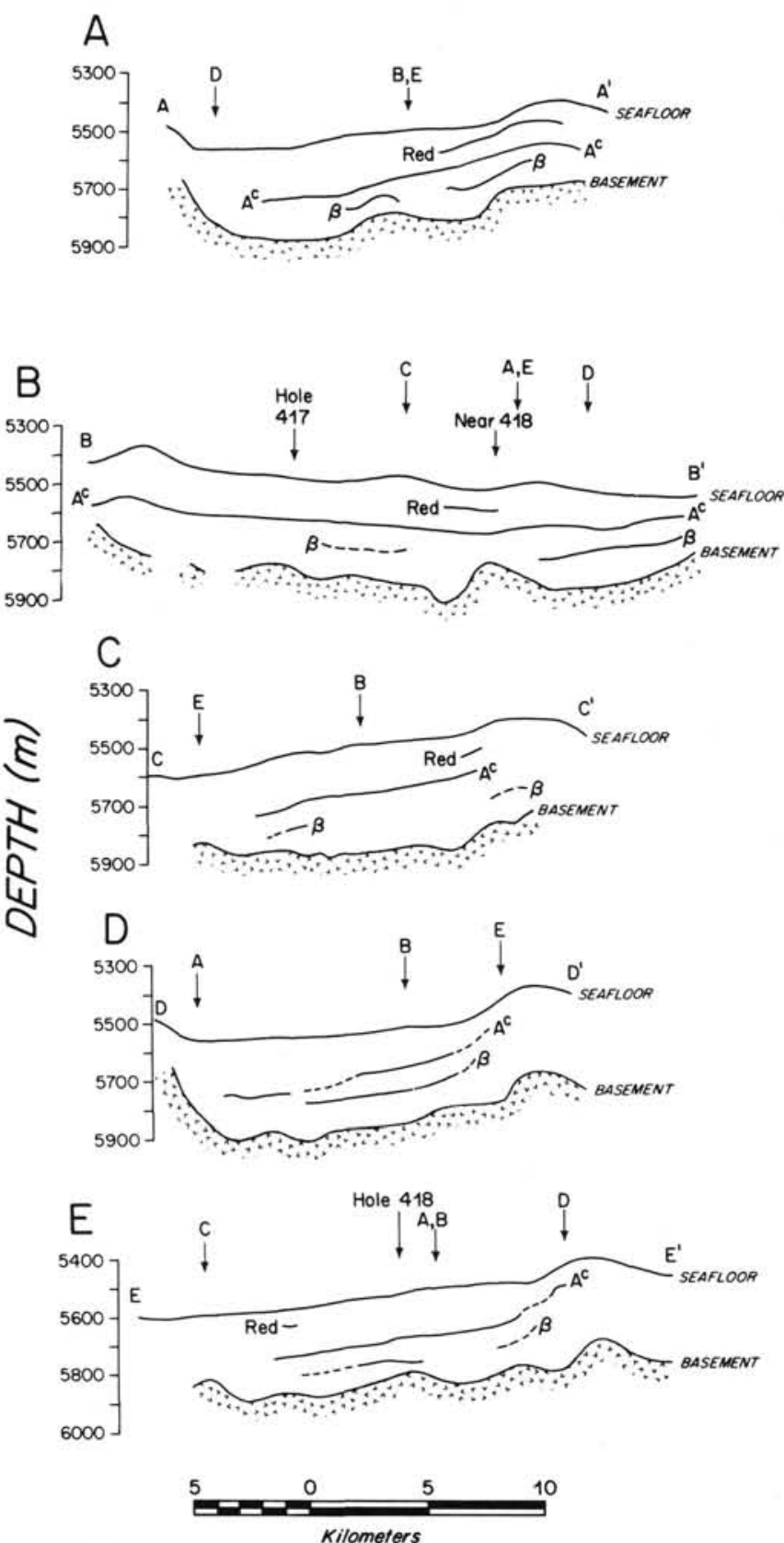

Figure 11. Cross sections in the vicinity of Sites 417 and 418 . Reflectors follow the same regional trend as basement topography. Seafloor topography reflects trends in basement highs. A. Line $A-A^{\prime}$. Basement is characterized by a series of plateaus with depth increasing from east to west. Reflectors $\beta, \mathrm{A}^{\mathrm{c}}$, and red parallel the regional slope of basement. B. North-south line B-B' . Short-wavelength basement features are not reflected in the overlying sediments, suggesting they were filled early in the history of the region. $\mathrm{C}$. Line $\mathrm{C}-\mathrm{C}^{\prime}$, perpendicular to spreading direction. Horizon $\beta$ pinches out near basement. Reflectors dip toward the northwest. D. Line D-D', perpendicular to spreading direction. Horizon $\mathrm{A}^{\mathrm{c}}$ pinches out near a basement high. $\mathrm{E}$. NNE line $\mathrm{E}-\mathrm{E}^{\prime}$. The cross section passes through Site 418 indicating location of drilling penetration for $\mathrm{A}^{\mathrm{c}}, \beta$, and basement.

than a chert layer. Although there is no compelling evidence from the lithologic data for a discontinuity at the level of this reflector, velocity and density data suggest one exists. The results of this study are preliminary and additional modeling needs to be carried out to better establish the nature of this reflector.
Sediments deposited between the middle Eocene and Quaternary show a dominant lithology of pelagic clays interbedded with terrigenous sediments. Several ash layers are observed near the level of the red reflector, which suggests that they may give rise to this reflection. During this time, the seafloor is believed to have been modified by strong bottom currents producing sediment drifts.

Several reflectors identified on profiles obtained during the initial occupation of Sites 417 and 418 correlate with reflectors observed in our data. Specific examples include reflectors 4 and 2 of Hole 417D, at 0.271 and 0.180 s TWT bsf (Donnelly, Francheteau, et al., 1980), which correlate with our picks for $\beta$ and $\mathrm{A}^{\mathrm{c}}$. At Holes 418A and 418B, a reflector observed at $0.20 \mathrm{~s}$ TWT bsf also correlates with the horizon we identified as $\mathbf{A}^{\mathrm{c}}$.

Left-lateral offset of magnetic anomaly $M 0$ indicates the presence of a transform fault northeast of Site 417 (Donnelly, Francheteau, et al., 1980). Bathymetric data have not proved useful in determining offset of geologic structures or the exact location of the fracture zone. Mapping of basement topography has allowed us to identify a fault associated with the fracture zone for the first time. We have measured up to $7 \mathrm{~km}$ of basement offset on this fault. We also observe a northwest trend of structural contours of seafloor and sedimentary horizons north of Site 417. These trends appear to be controlled by basement structures associated with the fault.

\section{ACKNOWLEDGMENTS}

This work was supported by National Science Foundation grant OCE-8416633. We wish to thank J. A. Austin, Jr., M. H. Salisbury, J. H. Scott, B. Tucholke, G. S. Mountain, and E. Uchupi, whose reviews and comments greatly improved this manuscript. We would also like to thank S. T. Bolmer for his assistance in data reduction.

Woods Hole Oceanographic Institution contribution No. 6334.

\section{REFERENCES}

Auroux, C. A., and Stephen, R. A., 1986. Geophysical profiling, ODP Leg 102. In Salisbury, M. H., Scott, J. H., et al., Proc. ODP, Init. Repts., 102: College Station, TX (Ocean Drilling Program), 791.

Donnelly, T., Francheteau, J., Bryan, W., Robinson, P., Flower, M., Salisbury, M., et al., 1980. Init. Repts. DSDP, 51, 52, 53, Pt. 1: Washington (U.S. Govt. Printing Office), 23-626.

Emery, K. O., and Uchupi, E., 1984. The Geology of the Atlantic Ocean: New York (Springer-Verlag), 104-106, Charts IIA and XA.

Ewing, M., and Ewing, J. I., 1963. Sediments at proposed LDGO drilling sites. J. Geophys. Res., 68:251-256.

Kent, D. V., and Gradstein, F. M., 1986. A Jurassic to Recent chronology. In Vogt, P. R., and Tucholke, B. E. (Eds.), The Western North Atlantic Region (1st ed.): Boulder, CO (Geological Society of America), 45-50.

Lancelot, Y., Hathaway, J. C., and Hollister, C. D., 1972. Lithology of sediments from the western North Atlantic Leg 11 Deep Sea Drilling Project. In Hollister, C. D., Ewing, J. I., et al., Init. Repts. DSDP, 11: Washington (U.S. Govt. Printing Office), 901-949.

Purdy, G. M., Ewing, J. I., and Bryan, G. M., 1980. A deep-towed hydrophone seismic reflection survey around IPOD Sites 417 and 418 . Mar. Geol., 35:1-19.

Rabinowitz, P. D., Hoskins, H., and Asquith, S. M., 1980. Geophysical site survey results near Deep Sea Drilling Project Sites 417 and 418 in the central Atlantic Ocean. In Donnelly, T., Francheteau, J., Bryan, W., Robinson, P., Flower, M., Salisbury, M., et al., Init. Repts. $D S D P, 51,52,53$, Pt. 1: Washington (U.S. Govt. Printing Office), 629-669.

Tucholke, B. E., 1979. Relationships between acoustic stratigraphy and lithostratigraphy in the western North Atlantic Basin. In Tucholke, B. E., Vogt, P. R., et al., Init. Repts. DSDP, 43: Washington (U.S. Govt. Printing Office), 827-846.

1981. Geologic significance of seismic reflectors in the deep western North Atlantic Basin. In Warme, J. E., Douglas, R. G., and 
Winterer, E. L. (Eds.), The Deep Sea Drilling Project, a Decade of Progress. Spec. Publ. Soc. Econ. Paleontol. Mineral., 32:32-37.

Tucholke, B. E., and Mountain, G. S., 1979. Seismic stratigraphy, lithostratigraphy and paleosedimentation patterns in the North American Basin. In Talwani, M., Hay, W., and Ryan, W. B. F. (Eds.), Deep Drilling Results in the Atlantic Ocean: Continental Margins and Paleoenvironment. Am. Geophys. Union, Maurice Ewing Ser., 3:5886.
Tucholke, B. E., and Vogt, P. R., 1979. Western North Atlantic: Sedimentary evolution and aspects of tectonic history. In Tucholke, B. E., Vogt, P. R., et al., Init. Repts. DSDP, 43: Washington (U.S. Govt. Printing Office), 791-825.

Date of initial receipt: 25 June 1986 Date of acceptance: 24 March 1987 Ms 102B-116

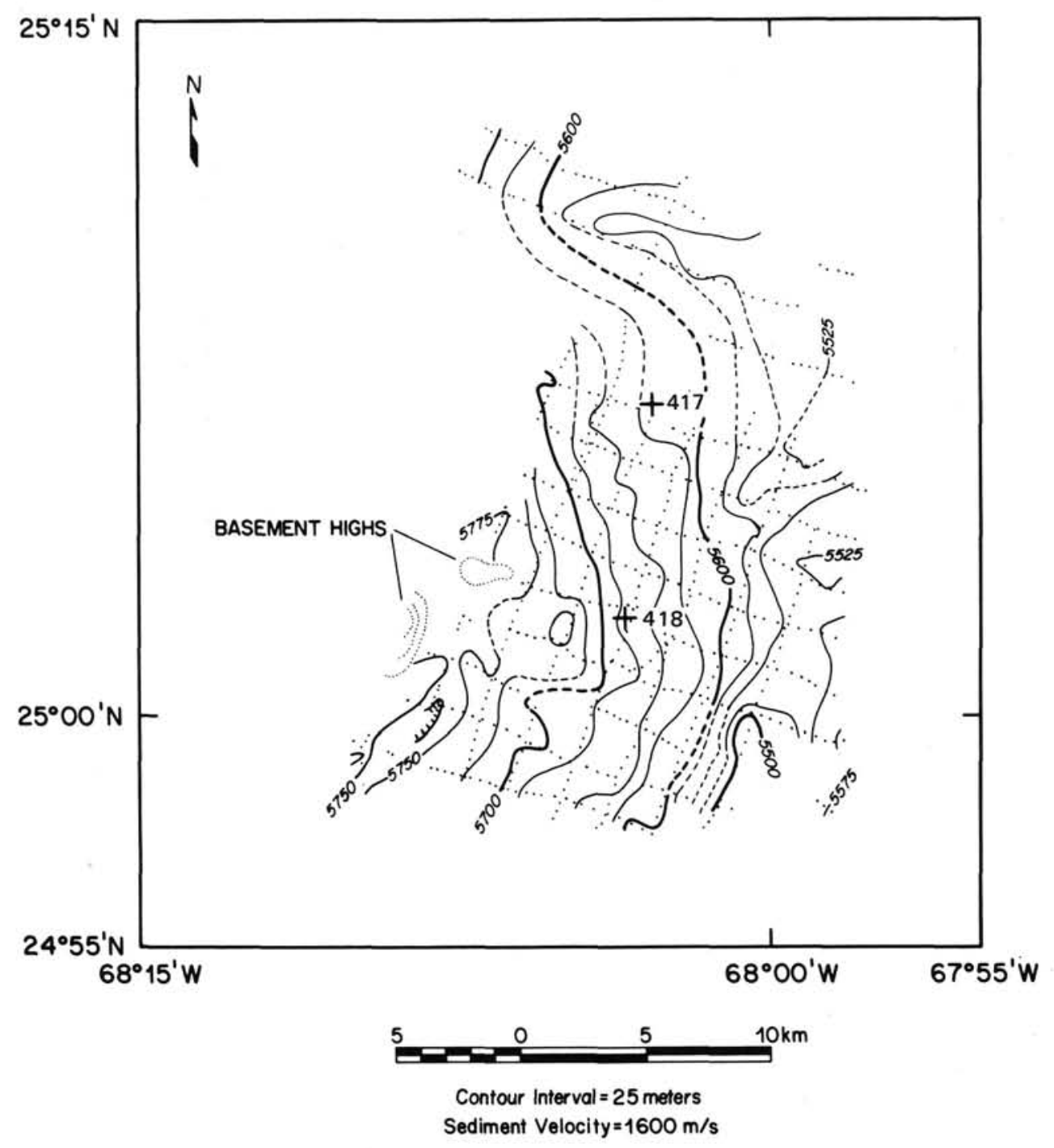

Figure 12. Depth to middle Eocene horizon $\mathbf{A}^{\mathrm{c}}$. Contours reflect the same general trend of present seafloor topography. Two basement highs penetrate sediments in the southwest region of the study area. 


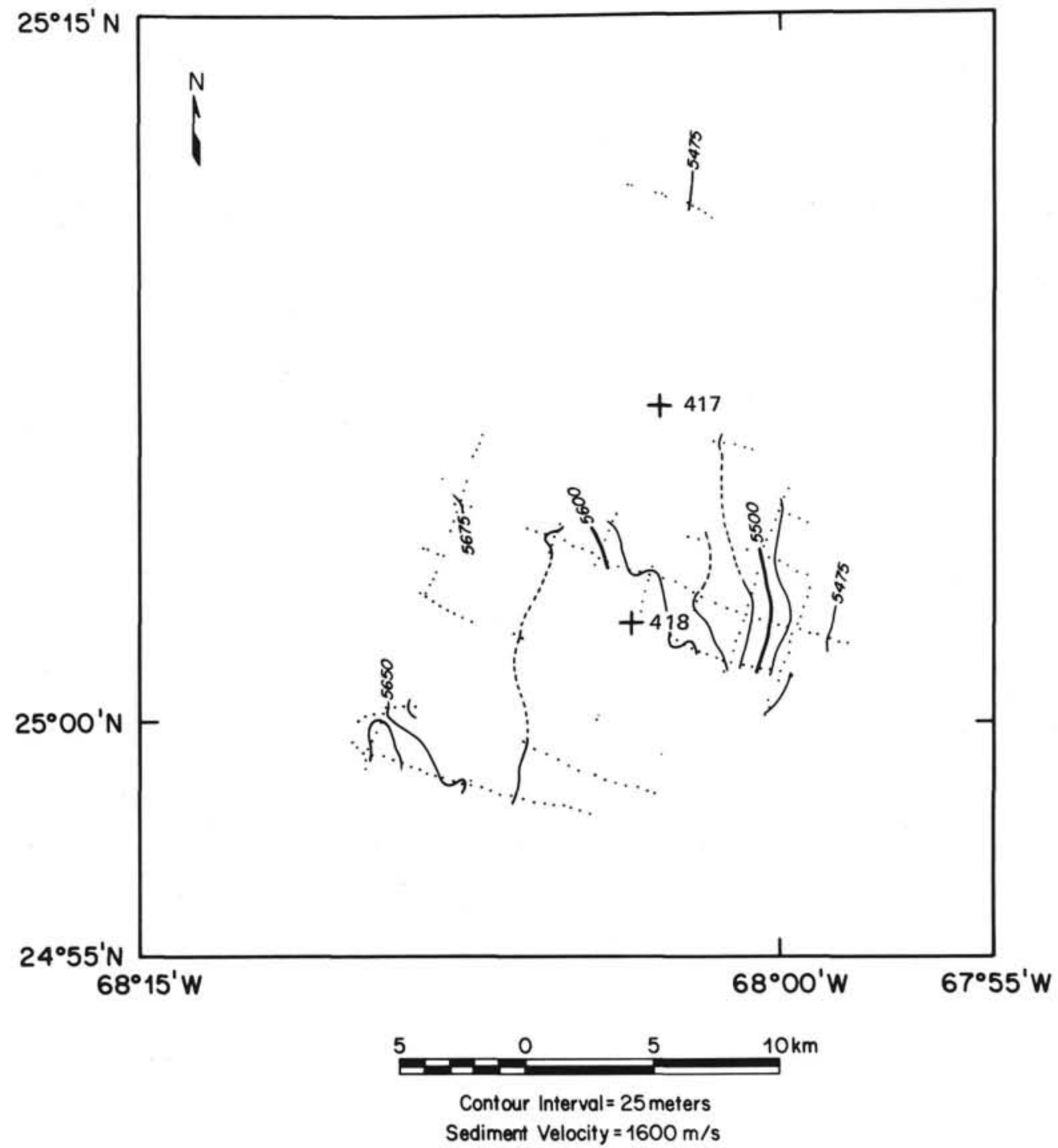

Figure 13. Depth to a weak Miocene-Oligocene reflector (red). The horizon is probably an ash deposit. 


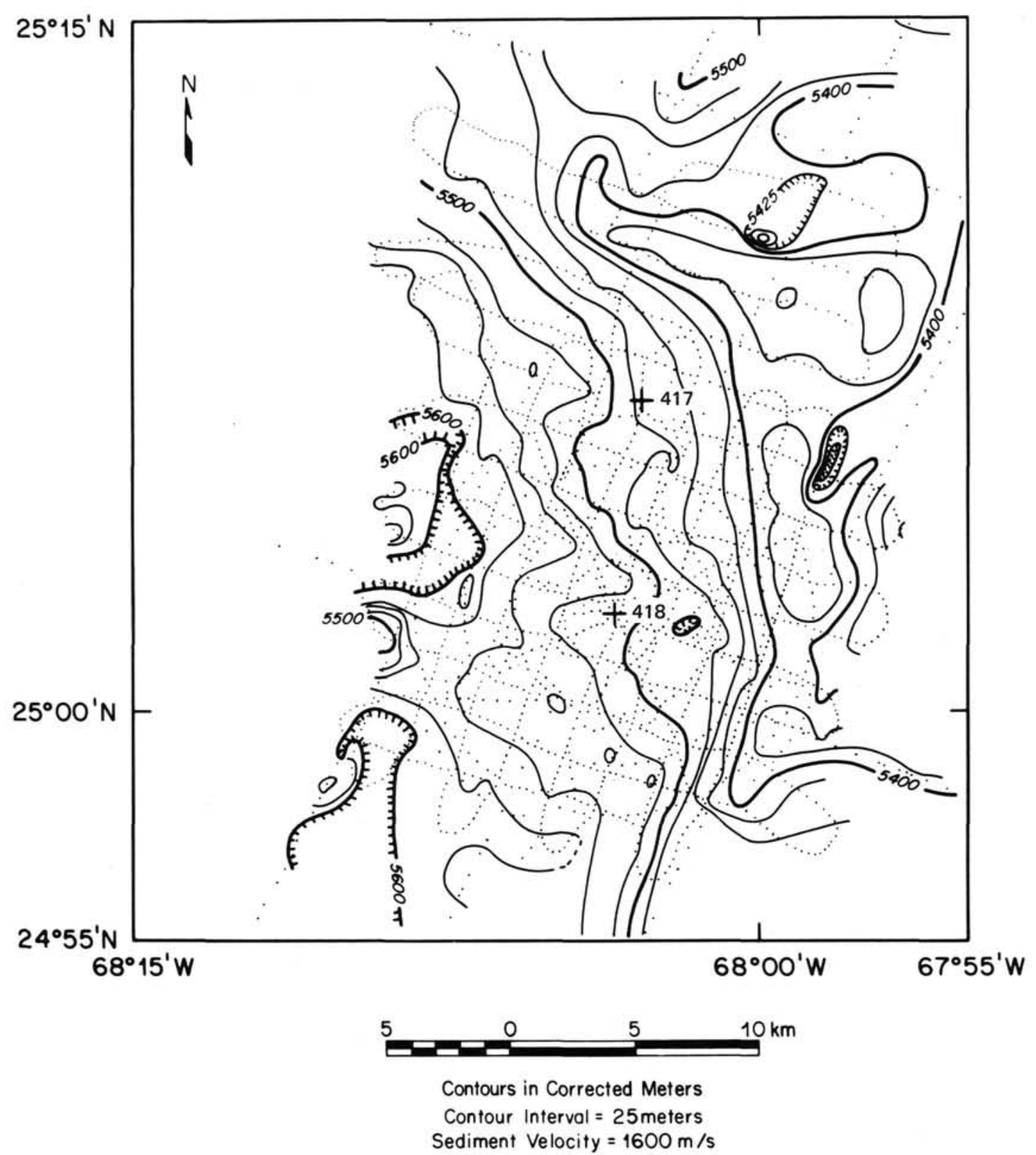

Figure 14. Bathymetry near Sites 417 and 418 . Relief dips gently to the west. Both sites are near the edge of a broad valley. Data from the 1976 Lynch site survey have been included in the data base. 


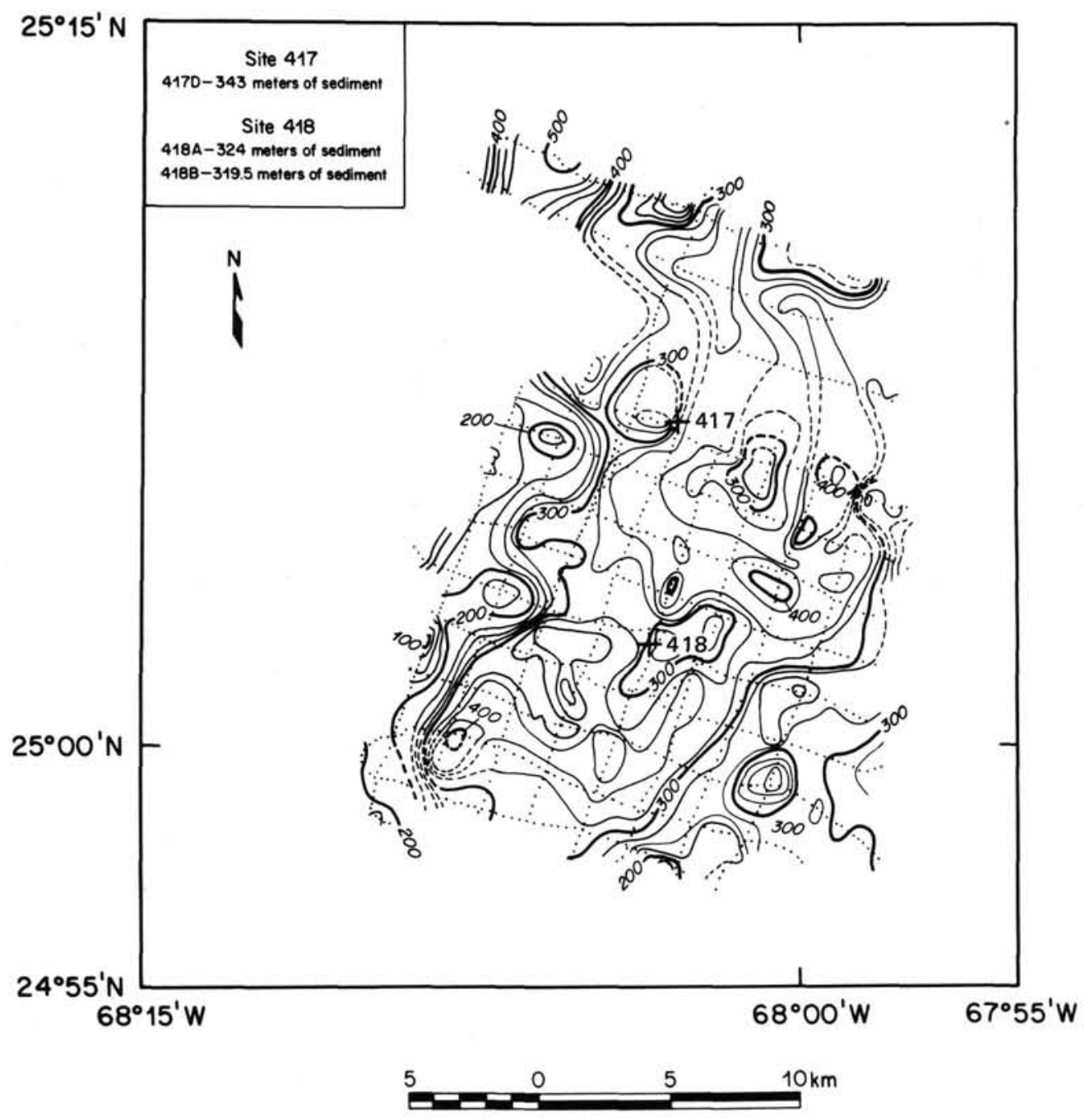

Contour Interval $=25$ meters

Sediment Velocity $=1600 \mathrm{~m} / \mathrm{s}$

Figure 15 . Total sediment thickness is relatively uniform at approximately $300 \mathrm{~m}$. Thickest sediments are found over basement depressions; thinnest over basement highs. 